\title{
The changing landscape of religious affiliation in Brazil between 1980 and 2010: age, period, and cohort perspectives
}

\author{
Raquel Zanatta Coutinho* \\ André Braz Golgher ${ }^{* *+}$
}

There has been a remarkable decline in the number of Catholics in Brazil over the last few decades, a fact that is attributed to the growth of Pentecostal churches and to an increase in the number of people with no religious affiliation. We analyzed the age, period, and cohort effects associated with religious affiliation in Brazil from 1980 to 2010, applying the Hierarchical Age-Period-Cohort and Cross-Classified Random Effects Model. We observed that age effects were significant but low for Catholics and Pentecostals, and were substantial for those with no religious affiliation, with a negative relationship. For these first two religious affiliations, period effects were of greater magnitude with clear trends: negative for Catholics and positive for Pentecostals. Cohort effects were significant for all three affiliations, but magnitudes were lower than the other two effects. We also verified that the likelihood of being a Pentecostal decreased with formal education, and the opposite occurred for persons with no religious affiliation. These effects, however, were smaller for younger cohorts, possibly due to the reduced social selectivity of recent students pursuing higher education and the increase in overall levels of education.

Keywords: Religious affiliation. Age-period-cohort Analysis. Cross-Classified Random Effects Models. Brazil.

\footnotetext{
* This research received support from the Population Research Infrastructure Program (R24 HD050924) awarded to the Carolina Population Center at The University of North Carolina at Chapel Hill by the Eunice Kennedy Shriver National Institute of Child Health and Human Development.

** University of North Carolina - UNC, Chapel Hill, North Carolina, USA (raquelzc@live.unc.edu).

${ }^{* * *}$ Centro de Planejamento Regional - Cedeplar/Faculdade de Ciências Econômicas - Face/Universidade Federal de Minas Gerais - UFMG, Belo Horizonte-MG, Brazil (agolgher@cedeplar.ufmg.br).
} 


\section{Introduction}

The number of self-declared Roman Catholics in Brazil has declined enormously over the last few decades. According to the Brazilian Demographic Census, the percentage of Catholics fell from $95 \%$ in 1940 to $65 \%$ in 2010 . This remarkable reduction is mainly attributed to the growth of Pentecostal churches. The proportion of Protestants increased from 3\% to $22 \%$ during the same period. Moreover, there was an increase in the number of persons with no religious affiliation, which varied from $1 \%$ to $8 \%$ of the total (ALVES et al., 2012; ALMEIDA; BARBOSA, 2013; ALMEIDA; MONTERO, 2013). People who declared themselves as members of "other religions" increased from $2 \%$ to $5 \%$ during the same period, also contributing slightly to the changing landscape of religious affiliation in Brazil.

These trends in religious affiliation may have impacts on many aspects of life in Brazil. Religion is likely to influence one's view of the world by creating and sharing symbolic meanings and rituals, and by shaping social and political attitudes (STEENSLAND et al., 2000). When Brazilians switch affiliations or decide to abandon religious life, what are they searching for? A conversion from one religion to another might represent the expression of different needs at the societal and individual levels, such as the search for spiritual comfort and/or the search for financial assistance and social capital, which religious services often provide. In this venue, the recent expansion of Pentecostal and neo-Pentecostal churches, which have attracted millions of members, especially in population strata with low income and less formal education, may have been fostered by these specific needs (DECOL, 1999; MARIANO, 2004; PIERUCCI, 2004; COSTA et al., 2005; ALVES; NOVELLINO, 2006; MCKINNON et al., 2008; ALVES et al., 2012; ALMEIDA; MONTERO, 2013; ALMEIDA; BARBOSA, 2013).

On the other hand, the shift toward "no affiliation" may be an indication of secular changes, suggesting that religion may no longer be dictating the norms, shaping the identities and influencing the values for particular groups in the Brazilian population.

The fact that Brazilians have witnessed and carried out a massive shift toward more conservative groups at the same time that more people have chosen to go without any religious affiliation has stimulated the scientific debate searching for explanations for the religious diversification and the decline of Roman Catholic hegemony. Demographers became encouraged to investigate major differences in cults and church participation (VERONA, 2010) and to explore the transformations in the religious landscape according to population composition.

Decol (1999) analyzed religious affiliation trends in Brazil up until the census of 1991. Pierucci (2004) also discussed these trends and included data from the 2000 demographic census. Pierucci analyzed the Brazilian states separately and described in greater detail the African and African-Brazilian religions, such as Umbanda and Candomblé, which are also very diverse in their socio-demographic distribution (for more information on African and African-Brazilian religions, see ALMEIDA; BARBOSA, 2013; PIERUCCI, 2004). Alves, Barros and Cavenaghi (2012) and Almeida and Barbosa (2013) updated these studies, including data 
from 2010, the last Brazilian census. This trio of authors discussed the main trends of religious affiliation in Brazil, including age and sex distributions. Moreover, the authors presented these trends according to macro-regions and states in Brazil, and analyzed differences in fertility rates. Almeida and Barbosa (2013) applied an Age-Period-Cohort (APC) approach by using Intrinsic Estimators to analyze recent socioeconomic trends associated with religious affiliations, and emphasized the importance of life course variables and the intergenerational transmission of religious affiliation.

A next step in the research is to understand how compositional changes might be behind the dynamics of religion. For example, were these trends spread equally across all age groups and across all birth cohorts in the population, or have the changes been led by subgroups, such as the younger generations or those with specific characteristics, such as inhabitants of urban areas or people with low levels of education? We thus build on the work of these authors, discussing the main trends of religious affiliation in Brazil using an APC approach, which we will describe below.

In the APC approach, age, period, and cohort effects are analyzed separately in order to disentangle the contribution of each when discussing trends such as those highlighted above in relation to religious affiliation. When changes that take place in a society belong to a specific age group (or groups), the result is an age effect, in other words, aging-related developmental changes that occur in life. In this case, one might note that certain age groups, regardless of their cohort or period, share the same characteristics or face the same phenomenon. One example of this is the increased probability of developing chronic diseases with age when comparing older people with those in younger age groups. When changes occur in all age groups at the same time, this configures a period effect, which "reflects changes in social, historical and epidemiological conditions that are unique to a period and that affect all living conditions regardless of age or life stage" (YANG, 2011, p. 18). The economic crisis of 1929 in the United States and the terrorist attacks of 2011 are examples of period effects that are likely to affect society in which they occur as a whole. Finally, cohort effects refer to individuals who share specific experiences, such as being born in the same year or entering a university during the same period. For instance, according to Ryder (1965), birth cohorts represent the effect of formative experience, shaped not only by life conditions from the moment of birth but also by a continuous and shared exposure to historical and social factors that might affect living conditions throughout life, thus making the specific group unique. One example of a cohort effect is the baby boom cohort (those born between 1946 and 1964), who have peculiar characteristics that distinguish them from individuals in previous and later generations.

The APC approach can be applied with different methods. In the absence of longitudinal data to investigate long-term changes, recently developed statistical tools transform crosssectional data, such as the Census data used in this paper, into well-grounded synthetic cohorts that mimic the true birth cohorts (YANG, 2008). We applied a recently developed methodology consisting of the Hierarchical Age-Period-Cohort (HAPC) and the Cross-Classified 
Random Effects Model (CCREM), which overcame many of the limitations that previously plagued the APC approach (YANG; LAND, 2013). We will discuss some of these limitations in greater detail in the Methods section of this paper. For a more extensive discussion on the limitations of APC studies and how the HAPC/CCREM addresses them, see Yang and Land (2004), Yang et al. (2008) and Yang (2011).

By using this method, we were able to discuss changes in religious affiliations in Brazil between 1980 and 2010, disentangling the multiple effects of age, cohort, and period. We could also look at intra-cohort heterogeneity and socio-demographic effects.

In other words, the main objectives of this paper are to characterize the main trends of religious affiliation in Brazil, discuss the effects of APC associated with these trends, and show intra-cohort and socio-demographic heterogeneities. To pursue these objectives, the paper is divided into six sections, including this Introduction. In the second section we briefly describe the religious landscape in Brazil since its colonization, identifying some of the main factors that may have contributed to changes in the distribution of religious affiliation. Third section presents descriptive statistics on the topic, giving an overview of the main trends, based on the Brazilian Censuses from 1980 to 2010. Forth section presents the methodology, with details on the databases, the variables used in the empirical analysis, and the econometric models, which are the HAPC and the CCREM. In the fifth section, we present the results of the econometric models. The last section concludes the paper.

\section{The changing religious landscape of Brazil}

In the following paragraphs we briefly describe the religious panorama in Brazil since its colonization and identify some of the key factors that seem to have contributed to changes in the distribution of religious affiliation in the country.

Roman Catholicism became the main religion in Brazil as the result of its colonization by Portugal. In the mid-sixteenth century Catholic congregations were already an important part of life of many Brazilian inhabitants, not only the Portuguese immigrants themselves, but also native Brazilians, who were the focus of evangelization (OLIVEIRA, 2008). During the colonial period, Catholicism became the official religion in Brazil, while other cults and religions were discouraged or forbidden, such as those that originated in Africa (FRAGOSO, 1994).

Brazil received a sizable flow of immigrants at the end of the nineteenth century, and this influx affected the religious landscape, as French, British, American, and German immigrants, among others, brought Protestantism to the country (OLIVEIRA, 2008). Protestant denominations were allowed, as long as they did not have the intention of converting Brazilian Catholics. During this period, Anglican communities, and Baptist and Presbyterian churches were introduced mostly in the Southern and Southeastern macro-regions.

Some other important changes occurred in the twentieth century. Classical Pentecostals arrived in Brazil in the 1910s, but their influence remained restricted to the Northern macroregion of the country for many decades. The second Pentecostal generation came to Brazil 
in the 1950s. American missionaries arrived in São Paulo, contributing to the expansion of Pentecostalism in the country. Since then, many Pentecostal churches have been established. These churches are known for promoting poverty and simplicity as virtues, while avoiding misery and greed (BURDICK, 1993).

The Catholic Charismatic Renewal (CCR), which introduced in Brazil in 1970, is in many aspects similar to the Pentecostal churches (CHESNUT, 1997; ALMEIDA; MONTERO, 2013). During services, worshippers of both affiliations dance, read the bible, emphasize the power of words, preach the commandments, and stress the relevance of values, such as virginity until marriage, and have considerable attendance at services and other liturgical celebrations. The CCR, although considered Catholic, competes for the same souls as the Pentecostal churches and has recently gained ground among the lower and middle classes and among young people (CHESNUT, 1997). The growth of Charismatic groups increased religious heterogeneity among Catholics, since it encompasses persons with strong religious values, an example being CCR members, as well as less religious persons, such as nominal Catholics (PIERUCCI; PRANDI, 2000 in VERONA, 2010).

Considered the third Pentecostal wave, neo-Pentecostalism has seen the most remarkable increase in the number of members in Brazil in the last few decades, especially in urban areas (ALVES; BARROS; CAVENAGHI, 2012). Based on the principles of the Theology of Prosperity, neo-Pentecostalism preaches that success, happiness, and prosperity can be achieved during their earthly life. They are denominated neo-Pentecostal churches because they differ greatly from historical Protestant and Pentecostal churches, rejecting traditional uses and customs. They are also more liberal on moral issues and less rigid than traditional Pentecostal churches concerning the behavior of their members (CHESNUT, 1997). Pastors make use of testimonials and communication campaigns to ensure massive cash donations and to attract more members (FRESTON, 1993; CHESNUT, 1997; MARIANO, 2004).

Some social aspects might in part explain why Pentecostal and neo-Pentecostal churches became so popular in Brazil. In 1980 a major economic crisis caused by inflation as well as a political and external debt crisis brought unemployment and poverty to most regions of the country (FERNANDES; PAES, n/d). A remarkable increase in crime rates during the 1980s, mostly in poor urban neighborhoods, led to a need for spiritual protection (CHESNUT, 2000). To mitigate the effects of persistent poverty and violence, Pentecostal and neo-Pentecostal churches provided material aid, psychological support, and even jobs. Consequently, many low socioeconomic status (SES) individuals were attracted to them. Almeida and Montero (2013) explain that one way to conceptualize this type of religious conversion is by understanding faith as a product that people can acquire in the religious market according to their needs.

Pentecostal and neo-Pentecostal church meetings and services also alleviate other problems associated with poverty and violence, such as alcoholism and drug abuse, which most often affect men. Many women in Brazil join these churches as a first step in overcoming household troubles related to these problems, and then they at least try to persuade their husbands to join. In fact, Brazilian women are overrepresented in all religious affiliations. This 
gender gap in religiosity has been examined in the sociological literature, but deserves further and updated investigation (SOUZA, 2007). One hypothesis for the greater involvement of women in religious faiths concern the female role in the church and in the organization of the household. It is possible that the increasing proportion of women who are the heads of their households has contributed to a divergence with patriarchal society and other institutions that have dictated norms for Brazilian families in the past, such as the Catholic Church.

According to Verona (2010), the appeal of Pentecostals and neo-Pentecostal churches to Brazilian youth is very strong. These churches promote youth meetings with festivities, career training, and other events that increase social and human capital for teenagers and young adults (SMITH, 2003). For instance, young people who live in less-privileged areas report going to church on Saturday nights because this is the only activity they can participate in that is free of charge and close to home (VERONA, 2010).

According to Almeida and Barbosa (2013), the religious transition is only part of a greater social change. Other changes in Brazilian society might also have contributed to variations in religious affiliation, although indirectly, such as demographic trends (fertility decline and fertility differentials, population aging, and rising life expectancy), and socioeconomic trends (increasing levels of education and urbanization).

As fertility rates began to decline in the 1960s and life expectancy increased, older cohorts became relatively more numerous than younger cohorts. Past studies have suggested that older individuals are more religious than younger ones because of the proximity to death and the greater need for social contact after retirement, which causes this population to turn to the churches. This trend is due in part to the churches' role in providing social support and networks for the elderly (LEVIN; CHATTERS; TAYLOR, 2010). Alves, Barros and Cavenaghi (2012) find that the elderly are underrepresented among the non-religious, and they suggest that this could be a sign that people tend to choose a religion as they grow older.

On the other hand, socioeconomic trends and ideational changes, such as rising levels of formal education and urbanization, may be promoting the idea of secularization (VAN DE KAA, 1987). Spirituality loses ground to rationality and materialism, especially among the younger population and among groups with higher levels of education (DECOL, 1999). Secularization could then be one reason for the increase in the number of persons with no religious affiliation, termed here as "with no religious affiliation". Classifying oneself in this category, however, does not necessary imply being an atheist or an agnostic, but that one does not profess any specific religious affiliation. Recent research has shown how the group of non-religious Brazilians has been growing over the years, and particularly, how males, children, adolescents and youth are overrepresented in this group (ALVES; BARROS; CAVENAGHI, 2012; ALMEIDA; MONTERO, 2013; ALMEIDA; BARBOSA, 2013). Almeida and Montero (2013) find that this group has a higher educational level compared to the average population. Nevertheless, Almeida and Barbosa (2013) conclude that the non-religious are also becoming more represented among the poor, the Blacks, and persons with low levels of education. 
In terms of the intergenerational transmission of religious affiliation, Alves, Barros and Cavenaghi (2012) show how the fertility rates of Pentecostals are higher than that of the other affiliations. In addition, since the majority of the members of Pentecostal churches are women of reproductive age, these groups seem to have an advantage over others (ALVES; BARROS; CAVENAGHI, 2012).

We have described two trends among the younger cohorts. First, younger individuals may show greater likelihood to be affiliated to Pentecostalism and neo-Pentecostalism and, at the same time, they might show a higher probability of becoming part of the no-religious affiliation group. The heterogeneity of the Brazilian population explains these apparently diverging trends, a clear indication of religious plurality.

The theoretical discussion above has introduced some of the main points that we analyze empirically in the following sections. Next, we present an overview of the Brazilian religious landscape using descriptive statistics.

\section{Overview of the religious landscape in Brazil}

The main objective of this section is to provide an overview of the main tendencies of the religious landscape in Brazil from 1980 to 2010, as the country goes through a process of religious diversification (ALVES; BARROS; CAVENAGHI, 2012). This section presents some descriptive features of this process and it has similarities with the findings of Almeida and Barbosa (2013) and Alves, Barros and Cavenaghi (2012). We therefore included some of their main conclusions in the discussion of our results.

We used Census micro data available at IPUMS-International (MINNESOTA POPULATION CENTER, 2011) and from the Brazilian Institute of Geography and Statistics - IBGE (2010). Table 1 shows the distribution, the sex ratio, and the degree of urbanicity of each religious affiliation by year. Initially, we discuss the distribution of the Brazilian population according to the main religious groups. We stated above that the proportion of Catholics in Brazil declined considerably remarkably between 1980 and 2010. The table shows that in only thirty years the percentage of Catholics fell from $88.3 \%$ to $65.4 \%$. These changes occurred mostly due to the relative number of Pentecostals and neo-Pentecostals, which increased sharply during the period, from approximately $3 \%$ to $20 \%$. This same increasing tendency was observed for people with no religious affiliation which corresponded to $8 \%$ of the Brazilian population in 2010. Two categories, Protestants and other religions, showed less-remarkable tendencies with approximately stable numbers.

These same trends were observed by Almeida and Barbosa (2013) and Alves, Barros and Cavenaghi (2012). The former study also described some of the trends of particular Protestant and Pentecostal affiliations as well as other religions not dealt with here. They showed, for instance, variations in the proportion of Jehovah's Witnesses, Candomblé and Buddhists.

Table 1 also shows the sex ratios for each affiliation by year. For Catholics, the ratio was reasonably stable and with a figure similar to that of the Brazilian population in general. 
This is partially due to the country's historical development since colonial times. As noted above, sex ratios might be especially low for recently established churches, as observed for neo-Pentecostals in 1991 and 2000. For Protestant, Pentecostal, and other affiliations in all years and for neo-Pentecostals in 2010, sex ratios were quite similar, a little more than 70 men for every 100 women. These results suggest that the affiliation of women is the initial step in the dynamics of a new church, followed by a second phase when there is an increase in the sex ratio. Conversely, males dominate the "No Religious Affiliation" category, as expected. Alves, Barros and Cavenaghi (2012) also discussed trends for sex ratios with similar conclusions and in greater detail.

TABLE 1

Religions affiliation distribution, sex ratio, and degree of urbanicity Brazil - 1980-2010

\begin{tabular}{lrrrr}
\hline \multicolumn{1}{c}{ Religion } & $\mathbf{1 9 8 0}$ & $\mathbf{1 9 9 1}$ & $\mathbf{2 0 0 0}$ & $\mathbf{2 0 1 0}$ \\
\hline Distribution (\%) & & & & \\
No religion & 1.9 & 4.6 & 6.9 & 8.0 \\
Catholic & 88.3 & 82.5 & 73.9 & 65.4 \\
Protestant & 3.5 & 4.0 & 4.4 & 4.0 \\
Pentecostal & 3.0 & 5.2 & 9.4 & 11.4 \\
Neo-Pentecostal & 0.0 & 0.3 & 1.8 & 6.7 \\
Other & 3.3 & 3.4 & 3.6 & 4.5 \\
\hline Sex ratio & & & & \\
No religion & 200 & 170 & 183 & 164 \\
Catholic & 98 & 96 & 97 & 98 \\
Protestant & 80 & 75 & 72 & 73 \\
Pentecostal & 76 & 70 & 71 & 73 \\
Neo-Pentecostal & - & 45 & 51 & 71 \\
Other & 82 & 69 & 67 & 71 \\
\hline Degree of urbanicity & & & & \\
No religion & 87.5 & 89.3 & 88.6 & 90.6 \\
Catholic & 69.9 & 76.6 & 81.1 & 82.9 \\
Protestant & 74.8 & 82.5 & 87.2 & 88.9 \\
Pentecostal & 75.9 & 82.4 & 86.9 & 88.6 \\
Neo-Pentecostal & - & 94.1 & 94.8 & 94.2 \\
Other & 90.2 & 95.1 & 95.9 & 96.6 \\
Total & 71.3 & 78.4 & 83.2 & 85.7 \\
\hline Sol & & & & \\
\hline
\end{tabular}

Source: IBGE. Brazilian Demographic Censuses of 1980, 1991, 2000, and 2010.

As already pointed out, the degree of urbanization increased substantially in Brazil between 1980 and 2010. Table 1 shows that this number increased from $71.3 \%$ in 1980 to $85.7 \%$ in 2010 . Social and spatial segregation affected by this process may have had an impact on religious affiliation. For example, the Catholic church is less present in slums, while Pentecostals and neo-Pentecostal churches have gained importance in such areas. In part this has taken place because the latter denominations can function anywhere, and it is easy 
to scatter them throughout poor neighborhoods (McKINNON, POTTER, GARRARD-BURNETT, 2008; VERONA, 2010).

Table 1 shows the degree of urbanicity for each religious affiliation. The Catholic Church was slightly more rural than the overall population on all four censuses, in accordance with recent findings (ALMEIDA; BARBOSA, 2013; ALVES; BARROS; CAVENAGHI, 2012). On the other hand, all other denominations were more urban, especially the neo-Pentecostals, persons of other religions, and persons with no religious affiliation. According to Almeida and Barbosa (2013), the Pentecostal churches seem to promote a better response than the Catholic Church to the apparent disorder of the urban environment. Secularization, which is especially present in more educated and urban social strata, may be influencing the non-religious group. It is important to note that the group classified as "other religions" has mixed tendencies and encompasses heterogeneous groups, including religions that originated in Africa and Asia. Almeida and Barbosa (2013) show that religions originated in Africa were overrepresented in metropolitan regions.

Alves, Barros and Cavenaghi (2012) describe some trends for the large -regions and states in Brazil. Catholics were overrepresented in the Northeast and South, while the Pentecostals were overrepresented in the other three regions, namely, the Southeast, the North and the Central-West. Other religions and persons with no religious affiliation were more present in the Southeast (results not shown).

Table 2 shows the educational levels for each religious affiliation in 2010, measured in numbers of years of formal education. We do not show the data for the other years because the relative results were quite similar. The "Other religions" group had the highest educational level, whereas individuals affiliated with the Pentecostal denomination showed the lowest levels of education. But we did not expect to find that individuals in the neo-Pentecostal churches would show a similar educational profile as those in other denominations. Neither did we expect that the group with no religious affiliation would fail to show a higher level of education than the population in general.

TABLE 2

Religious affiliation distribution by education Brazil - 2010

Percentage

\begin{tabular}{lcccccc}
\hline \multirow{2}{*}{ Religion } & \multicolumn{7}{c}{ Completed years of schooling } \\
\cline { 2 - 6 } \multicolumn{1}{c}{} & $\mathbf{0}$ & $\mathbf{1}$ to $\mathbf{7}$ & $\mathbf{8}$ to $\mathbf{1 0}$ & $\mathbf{1 1}$ & $\mathbf{1 2}$ to $\mathbf{1 4}$ & $\mathbf{1 5}$ and more \\
\hline No religion & 8.9 & 36.0 & 17.6 & 21.9 & 5.9 & 9.6 \\
Catholic & 8.8 & 36.7 & 15.8 & 22.0 & 5.7 & 11.1 \\
Protestant & 4.4 & 28.0 & 16.2 & 27.8 & 9.2 & 14.4 \\
Pentecostal & 8.0 & 40.1 & 18.7 & 23.9 & 4.5 & 4.8 \\
Neo-Pentecostal & 5.9 & 32.9 & 18.5 & 26.6 & 6.8 & 9.3 \\
Other & 4.0 & 19.2 & 14.5 & 26.0 & 10.7 & 25.5 \\
Total & $\mathbf{8 . 1}$ & $\mathbf{3 5 . 6}$ & $\mathbf{1 6 . 4}$ & $\mathbf{2 2 . 9}$ & $\mathbf{6 . 0}$ & $\mathbf{1 0 . 9}$ \\
\hline
\end{tabular}

Source: IBGE. Brazilian Demographic Census of 2010. 
Table 3 shows the age distribution of each religious affiliation in 2010. The group with no religious affiliation was the youngest, while Pentecostals and neo-Pentecostals were only slightly younger than Catholics. Although the younger generations tend to show greater levels of formal education, these results do not partially explain the non-anticipated results of Table 2. Alves, Barros and Cavenaghi (2012) present some of these trends in detail.

TABLE 3

Age distribution by religious affiliation

Brazil - 2010

Percentage

\begin{tabular}{lrrrrr}
\hline \multicolumn{1}{c}{ Religion } & \multicolumn{5}{c}{ Age group } \\
\cline { 2 - 6 } & $\mathbf{2 0}$ to $\mathbf{2 9}$ & $\mathbf{3 0}$ to $\mathbf{3 9}$ & $\mathbf{4 0}$ to $\mathbf{4 9}$ & $\mathbf{5 0}$ to $\mathbf{5 9}$ & $\mathbf{6 0}$ to $\mathbf{6 9}$ \\
\hline No religion & 37.3 & 27.4 & 18.4 & 11.2 & 5.7 \\
Catholic & 28.2 & 24.1 & 21.1 & 16.2 & 10.4 \\
Protestant & 28.7 & 26.3 & 21.1 & 14.6 & 9.2 \\
Pentecostal & 29.3 & 26.7 & 21.0 & 14.3 & 8.6 \\
Neo-Pentecostal & 29.1 & 26.7 & 21.4 & 14.7 & 8.1 \\
Other & 24.2 & 24.9 & 22.8 & 18.0 & 10.2 \\
Total & $\mathbf{2 9 . 0}$ & $\mathbf{2 5 . 0}$ & $\mathbf{2 0 . 9}$ & $\mathbf{1 5 . 5}$ & $\mathbf{9 . 6}$ \\
\hline
\end{tabular}

Source: IBGE. Brazilian Demographic Census of 2010.

This section presented some descriptive statistics. Although these numbers provide important information, they do not allow a more insightful analysis of the main trends associated with religious affiliation. We further discuss these trends using the HAPC/CCREM method, which will be described in the next section.

\section{Methodology}

Here we investigate in greater detail the main trends of religious affiliation in Brazil between 1980 and 2010, using the Age-Period-Cohort approach. We briefly explained the approach in the introduction of this paper. Now, we will first provide more details about these databases and the variables used in the econometric models. Then we will present the Hierarchical APC and Cross-Classified Random Effects model (CCREM).

\section{Databases and variables}

We used four different Brazilian census databases from 1980 to 2010 to discuss religious affiliations in Brazil (for more information, see http://www.ibge.gov.br/home). We restricted our analysis to these datasets because of the availability of measurements on religion. However, it is advisable to use a greater number of periods when applying the HAPC/CCREM methodology (YANG, 2011).

In addition, because of the availability of data and the relative size of the Brazilian population affiliated with each religion, we analyzed only the following religions: Mainline Protestants, Pentecostals, neo-Pentecostals, Catholics, and persons with no religious 
affiliation. Spiritism, Judaism, Buddhism, and other religions originated in Africa and Asia did not present sufficient sample size in any of the four censuses to be considered for analysis. We assumed that respondents chose the affiliation that they considered as their main religion, and if they belonged to more than one, we assumed that they did not choose "no religion affiliation" as an option. Regardless of this, it is important to note that "no religious affiliation" does not necessarily mean "lack of religiosity". In addition, having a denomination does not automatically imply church attendance, but measuring attendance is beyond the scope of this paper. For a more detailed discussion on religious affiliation in Brazil and measurements of religion and religiosity, see Coutinho (2011).

We selected individuals between the ages of 20 and 70 in the 1980, 2000, and 2010 Censuses; but for the 1991 census, because of this one-year shift in research collection, we restricted our sample to individuals between 21 and 71. This minor change was necessary to obtain the same age groups for each census to use as a synthetic birth cohort. In the absence of longitudinal data, which allows the investigation of religious affiliation for the same individual over a long period and by cohort, we classified the census data into different five-year birth cohorts from 1900 to 1990 (MASON; FIENBERG, 1985; PRESTON; HEUVELINE; GUILLOT, 2001; YANG, 2011). The use of synthetic birth cohorts built with nationally representative samples effectively mimics longitudinal data for studies similar to this one (YANG, 2011).

The dependent variables in the models were dummies indicating whether each individual was affiliated to a specific religion (1 - yes) at the time of the interview. Besides religious affiliations, we included other variables in the econometric models, which we have already described in previous sections. These are: gender (male $=1)$; a urban/rural dummy ( $1=$ urban), as defined by the Brazilian Institute of Geography and Statistics (IBGE); a continuous variable for completed years of schooling (years of formal education); a dummy for post-secondary education, here called higher education (yes $=1$ ); age (continuous); and age squared (continuous). As we use the APC approach, we included the synthetic birth cohort (5-year interval) and period (year the Census was conducted: 1980, 1991, 2000, 2010). Since the country is regionally diverse, we also included a variable indicating the individual's macroregion of residence (North, Northeast, Southeast, or South. Central/West was the reference). People who failed to report a religious affiliation and also failed to report no affiliation were coded as missing and deleted from the analytic sample.

\section{Empirical strategy}

In Section 2, we presented descriptive statistics that showed some general trends concerning religious affiliation. This type of presentation, however, has certain limitations if the effects of age, period, and cohort are the focus of analysis. For instance, if older cohorts are more religious than younger ones, cross-section surveys may inaccurately classify cohort effects as age effects, i.e., there are confounding aspects of age and cohort effects (YANG et al., 2004). 
How can one proceed to disentangle these three effects? Depending on the method, the linear dependency among age, period, and cohort (period = age + cohort) could cause models using the APC approach to incur in problems of identification (GLEN, 1979). These problems make the assessment of the age, period, and/or cohort effects difficult (MASON; FIENBERG, 1985 in YANG, 2011).

Yang et al. (2004; 2008), and Fu (2008) listed several methods that address these limitations, such as the Intrinsic Estimator and the Constrained Generalized Linear Method. For an example of the Intrinsic Estimator in studies on religion in Brazil, see Almeida and Barbosa (2013). These methods, however, have certain drawbacks (YANG et al., 2004). More recent analytic advances provide some leverage on these limitations while using the APC approach (YANG et al., 2008), such as the Hierarchical APC model for repeated crosssection surveys, applying a Cross-Classified Random Effects Model (CCREM). Thus, to capture the APC effects on religious affiliation in Brazil, we used this latter method, as suggested by Yang et al. (2008). This method was recently criticized by Bell and Jones (2014) in points related to its applicability. However, for an extensive discussion about the method see Yang and Land (2013).

The CCREM is a mix of fixed and random effects models, which characterizes contextual effect of historical time and cohort membership and can accommodate covariates, including those associated with social change (YANG, 2011). Similar to Yang et al. (2008), the model's first level in our analysis is represented by the following equation, which is similar to a logistic model:

$$
Y_{i j k}=\alpha_{j k}+\beta_{1 j k} A+\beta_{2 j k} A^{2}+\beta_{3 j k} M+\beta_{4 j k} E+\beta_{5 j k} S E+\beta_{6 j k} U+\sum_{z=7}^{10} \beta_{z j k} R_{z}+e_{i j k}
$$

where $i$ represents individuals, $j$ represents periods, and $k$ cohorts. $Y$ is the dependent variable for each religious affiliation; $\mathrm{A}$ is age; $\mathrm{M}$ is the male dummy; $\mathrm{E}$ is the four categories variable associated with education; $\mathrm{SE}$ is the dummy for higher education; $\mathrm{U}$ is the urban dummy; $\mathrm{R}$ are the four regional dummies; $\alpha$ and $\beta_{\text {s }}$ are the estimated coefficients; and $e_{i j k}$ is the random error.

Besides this first level, in order to overcome the problems of linear dependency among age, period, and cohort, the model also contains a second level. Therefore, only the variable age was included in the first level, while the second level incorporates equations for period and cohort effects.

The first equation in the second level of the model is the following:

$$
\alpha_{j k}=\pi_{0}+\tau_{0 j}+c_{0 k}
$$

where $\pi_{0}$ is the expected mean at the zero values of all level- 1 variables averaged over all periods and cohorts; $\tau_{0 j}$ is the overall period effect in terms of the residual random coefficients of period $j$ averaged over all birth cohorts; and $c_{0 k}$ is the overall cohort effect in terms of the residual random coefficients of cohort $k$ averaged over all time periods. 
In addition, we believe that effects due to sex and higher education might be different according to different periods and cohorts. Thus, we also incorporated two other equations in the second level, which are similar to the one above:

$$
\begin{aligned}
& \beta_{3 j k}=\pi_{3}+\tau_{3 j}+c_{3 k} \\
& \beta_{5 j k}=\pi_{5}+\tau_{5 j}+c_{5 k}
\end{aligned}
$$

where $\pi$ represents the fixed effects of sex or higher education level, and $\tau$ and $c$ are respectively the period and cohort effects. These equations enabled us to understand if the effects of these variables on religious affiliation varied between periods and cohorts.

We applied this method to analyze each religious affiliation separately using SAS 9.2. Given the size of our sample, more than 20 million observations, estimating the models with all of them was not computationally feasible. Therefore, we randomly selected $10 \%$ of the sample to facilitate the estimations without modifying the results. Our final sample size was composed of 2,526,958 individuals.

\section{Results of the econometric models}

In this section, we present the results for the CCREM as described by equations (1), (2), (3), and (4). In table 1 of the third section of this paper, we discussed the main trends of religious affiliation for individuals without affiliation, Catholics, Protestants, Pentecostals, neo-Pentecostals, and other religions. Given that Protestants were not numerous and trends were not remarkable, we decided not to discuss this group further. For the same reason, we excluded persons affiliated with "other religions" because they form a very heterogeneous group showing mixed trends that we will explore in a future paper. Lastly, the neo-Pentecostal churches have appeared very recently in Brazil, and there were very few Brazilians with this affiliation in 1980. We have consistent data only since 1991, and because of this scarcity of periods, we also excluded this group from our econometric models.

We conduct the analysis of the other three groups separately, namely, Catholics, Pentecostals, and No Religion. Table 4 shows the results of the three models. Most coefficients of equation (1) with the fixed effects were significant. Only the dummy for higher education for Catholics was not significant. On the other hand, many variables in equations (2), (3), and (4) with the random effects were not significant. We plot these coefficients into graphs to facilitate the discussion.

First we will discuss the results for Catholics, the largest Brazilian religious affiliation. The descriptive statistics section of this paper showed a sharp decrease in the proportions of individuals who declared themselves as Catholics between 1980 and 2010. This was the main trend, since the ratio for sex, education, and age profile were similar to the means presented by the overall population. Catholics had lower probability of living in urban areas when compared to the overall mean population. 
TABLE 4

Coefficients of the CCREM econometric models for religious affiliation Brazil - 1980-2010

\begin{tabular}{|c|c|c|c|}
\hline Variables & Catholics & Pentecostals & No religion \\
\hline \multicolumn{4}{|l|}{ Fixed effects } \\
\hline Intercept & $1.68^{\star}$ & $-2.71^{\star}$ & $-2.47^{\star}$ \\
\hline Age & $-0.0268^{\star}$ & $0.0372^{\star}$ & $-0.0125^{\star}$ \\
\hline Age squared & $0.0003^{*}$ & $-0.0004^{\star}$ & $-0.0002^{\star}$ \\
\hline Male & $0.09^{\star}$ & $-0.30^{\star}$ & $0.71^{\star}$ \\
\hline Education & $-0.08^{*}$ & $-0.12^{\star}$ & $-0.11^{\star}$ \\
\hline Higher Education & 0.060 & $-0.97^{\star}$ & $0.64^{\star}$ \\
\hline Urban & $-0.10^{*}$ & $0.08^{\star}$ & $0.04^{\star}$ \\
\hline North & $0.04^{\star}$ & $0.12^{\star}$ & $-0.13^{\star}$ \\
\hline Northeast & $0.62^{\star}$ & $-0.77^{\star}$ & $-0.12^{\star}$ \\
\hline Southeast & $0.01^{\star}$ & $-0.23^{*}$ & $0.05^{\star}$ \\
\hline South & $0.40^{\star}$ & $-0.53^{\star}$ & $-0.77^{\star}$ \\
\hline Central/West & ref. & ref. & ref. \\
\hline \multicolumn{4}{|l|}{ Random effects } \\
\hline \multicolumn{4}{|l|}{ Period } \\
\hline Intercept 1980 & $0.72^{\star}$ & $-0.86^{\star}$ & 0.04 \\
\hline Intercept 1991 & 0.21 & -0.19 & 0.41 \\
\hline Intercept 2000 & -0.33 & 0.45 & 0.52 \\
\hline Intercept 2010 & $-0.59^{\star}$ & 0.61 & $-0.97^{\star}$ \\
\hline Sex 1980 & $-0.08^{\star}$ & $0.08^{*}$ & -0.08 \\
\hline Sex 1991 & -0.03 & 0.00 & $-0.13^{\star}$ \\
\hline Sex 2000 & 0.02 & -0.03 & 0.08 \\
\hline Sex 2010 & $0.09^{*}$ & -0.06 & $0.13^{*}$ \\
\hline Higher Education 1980 & $-0.29^{\star}$ & -0.04 & $0.47^{\star}$ \\
\hline Higher Education 1991 & -0.09 & -0.07 & 0.01 \\
\hline Higher Education 2000 & 0.18 & 0.05 & -0.26 \\
\hline Higher Education 2010 & 0.21 & 0.06 & -0.22 \\
\hline \multicolumn{4}{|l|}{ Cohort } \\
\hline Intercept 1910 & $-0.30^{\star}$ & $0.19^{\star}$ & 0.21 \\
\hline Intercept 1915 & $-0.32^{\star}$ & $0.13^{*}$ & $0.22^{\star}$ \\
\hline Intercept 1920 & $-0.23^{*}$ & $0.13^{\star}$ & 0.03 \\
\hline Intercept 1925 & $-0.15^{\star}$ & 0.06 & 0.00 \\
\hline Intercept 1930 & -0.04 & -0.03 & -0.09 \\
\hline Intercept 1935 & 0.03 & -0.06 & $-0.14^{\star}$ \\
\hline Intercept 1940 & 0.05 & $-0.07^{\star}$ & $-0.10^{\star}$ \\
\hline Intercept 1945 & $0.11^{\star}$ & $-0.11^{*}$ & $-0.21^{\star}$ \\
\hline Intercept 1950 & $0.14^{\star}$ & $-0.13^{*}$ & $-0.14^{*}$ \\
\hline Intercept 1955 & $0.15^{\star}$ & $-0.14^{\star}$ & $-0.12^{\star}$ \\
\hline Intercept 1960 & $0.17^{\star}$ & $-0.14^{*}$ & $-0.10^{\star}$ \\
\hline Intercept 1965 & $0.13^{*}$ & $-0.07^{\star}$ & -0.03 \\
\hline Intercept 1970 & 0.09 & 0.00 & 0.04 \\
\hline Intercept 1975 & 0.06 & 0.04 & $0.12^{\star}$ \\
\hline Intercept 1980 & 0.05 & $0.10^{\star}$ & $0.17^{\star}$ \\
\hline
\end{tabular}

continue... 
...continued

\begin{tabular}{|c|c|c|c|}
\hline Variables & Catholics & Pentecostals & No religion \\
\hline Intercept 1985 & 0.07 & $0.10^{\star}$ & $0.15^{\star}$ \\
\hline Sex 1910 & -0.01 & 0.02 & 0.10 \\
\hline Sex 1915 & 0.04 & 0.02 & 0.15 \\
\hline Sex 1920 & 0.04 & 0.00 & $0.26^{\star}$ \\
\hline Sex 1925 & 0.03 & 0.01 & $0.37^{\star}$ \\
\hline Sex 1930 & 0.03 & 0.00 & $0.28^{\star}$ \\
\hline Sex 1935 & $0.08^{*}$ & -0.02 & $0.19^{\star}$ \\
\hline Sex 1940 & $0.08^{*}$ & $-0.05^{\star}$ & 0.11 \\
\hline Sex 1945 & $0.06^{*}$ & $-0.05^{\star}$ & $0.18^{\star}$ \\
\hline Sex 1950 & $0.07^{\star}$ & $-0.08^{*}$ & 0.03 \\
\hline Sex 1955 & 0.04 & $-0.07^{\star}$ & 0.02 \\
\hline Sex 1960 & -0.04 & 0.00 & -0.05 \\
\hline Sex 1965 & $-0.04^{\star}$ & 0.01 & $-0.16^{\star}$ \\
\hline Sex 1970 & $-0.08^{*}$ & $0.04^{*}$ & $-0.24^{\star}$ \\
\hline Sex 1975 & $-0.07^{\star}$ & 0.03 & $-0.36^{\star}$ \\
\hline Sex 1980 & $-0.08^{*}$ & $0.05^{\star}$ & $-0.43^{*}$ \\
\hline Sex 1985 & $-0.13^{*}$ & $0.09^{*}$ & $-0.46^{\star}$ \\
\hline Higher Education 1910 & -0.02 & 0.07 & 0.51 \\
\hline Higher Education 1915 & -0.02 & -0.08 & 0.17 \\
\hline Higher Education 1920 & 0.03 & -0.21 & 0.29 \\
\hline Higher Education 1925 & 0.02 & -0.44 & 0.04 \\
\hline Higher Education 1930 & -0.04 & -0.30 & $0.29^{\star}$ \\
\hline Higher Education 1935 & -0.05 & $-0.36^{\star}$ & $0.29^{\star}$ \\
\hline Higher Education 1940 & -0.05 & $-0.31^{\star}$ & $0.35^{\star}$ \\
\hline Higher Education 1945 & -0.03 & $-0.24^{\star}$ & $0.28^{*}$ \\
\hline Higher Education 1950 & $-0.07^{\star}$ & -0.01 & 0.11 \\
\hline Higher Education 1955 & $-0.05^{\star}$ & 0.03 & 0.01 \\
\hline Higher Education 1960 & -0.04 & 0.18 & -0.07 \\
\hline Higher Education 1965 & 0.03 & $0.29 *$ & $-0.32^{\star}$ \\
\hline Higher Education 1970 & 0.01 & $0.35^{\star}$ & $-0.35^{\star}$ \\
\hline Education 1975 & $0.09^{\star}$ & $0.30^{*}$ & $-0.48^{\star}$ \\
\hline Education 1980 & $0.09^{\star}$ & $0.29^{\star}$ & $-0.51^{\star}$ \\
\hline Education 1985 & $0.11^{\star}$ & $0.45^{\star}$ & $-0.62^{\star}$ \\
\hline
\end{tabular}

Source: IBGE. Brazilian Demographic Censuses of 1980, 1991, 2000, and 2010. Note: ${ }^{*} p<0.05$

In terms of the econometric models, Table 4 shows the fixed effects coefficients for Catholics. All of them were significant, except the dummy for higher education. For age, the coefficient was negative, and for age squared, it was positive, i.e., a decreasing and convex relation. Given the magnitude of these coefficients, we estimate that the relationship between age and the probabilities of being Catholic showed a minimum probability around the age of forty. The coefficient for the male dummy was positive and significant with small magnitude, indicating that males had a slightly greater likelihood of being Catholic, after controlling for the other variables in the model. For education, the coefficient was negative, and for higher education it was not significant, indicating that individuals with higher levels of education 
had a smaller probability of being Catholic, and that the relationship was approximately linear. The results also corroborated the tendency of Catholics to be slightly more rural, with a negative sign for the urban dummy. The regional dummies were all positive, with greater magnitude for the Northeast and Southeast, suggesting that Catholicism was relatively stronger in these regions.

The effect of the variables that were included as random effects are also better visualized with the aid of graphs. We do not discuss the random effects of the higher education variable, as it was insignificant. We also do not examine the random effects associated with sex, as sex ratios for Catholics were very similar to the overall population in all years. First, Graph 1 (A) brings the graphs based on the coefficients for intercepts and period with the period effects net of age and cohort.

Graph 1(A) shows the period effect for the four years, including the $95 \%$ confidence intervals. A decreasing trend can be seen indicating that this effect is possibly the most important explanation for the declining numbers of persons affiliated with the Catholic Church. Two coefficients were not significant, as the 0.5 relative probabilities are included in the confidence interval. However, trends are clear.

GRAPH 1

Period effects for the Catholic, Pentecostal and no-affiliation groups

Brazil - 1980-2010

A

B C

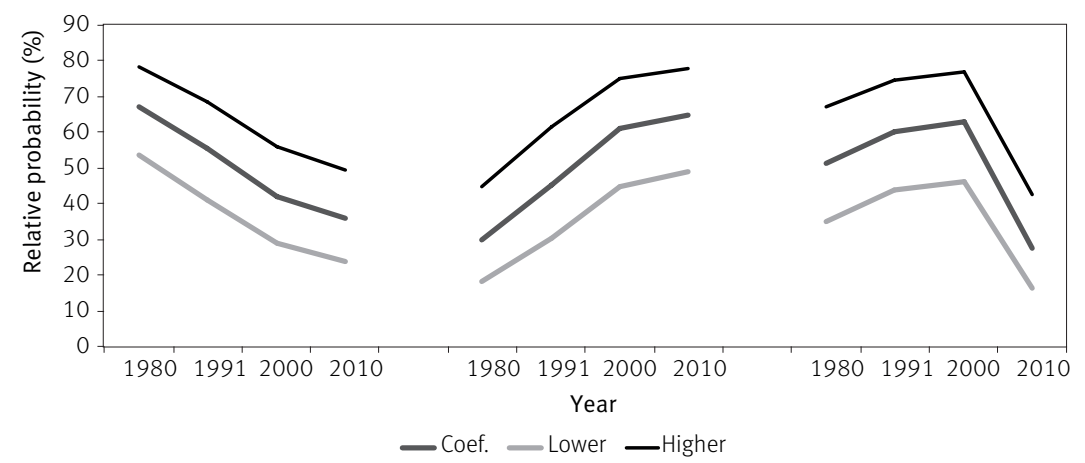

Source: IBGE. Brazilian Demographic Censuses of 1980, 1991, 2000, and 2010

Graph 2(A) shows the cohort effects net of age and period effects, which are based on the coefficient for intercepts and cohort. This graph shows that the coefficients for older cohorts were negative and significant, whereas. for cohorts born between 1945 and 1965, the coefficients were positive and significant. Cohort effects were much lower than period effects.

These results show that period effects indicate a decreasing tendency to be affiliated with the Catholic church and effects of age and cohort seem to have been less critical for the new landscape of affiliations. It was stated above that most individuals in Brazil were Catholic because of the historical development of the country. Therefore, it is possible that period 
effects, spurred on by the increased numbers of Pentecostals and persons with no religious affiliation, may be the drivers of the decline in the number of Catholics.

GRAPH 2

Cohort effects for the Catholic, Pentecostal and no-affiliation groups according to year of birth Brazil - 1980-2010

A

B C

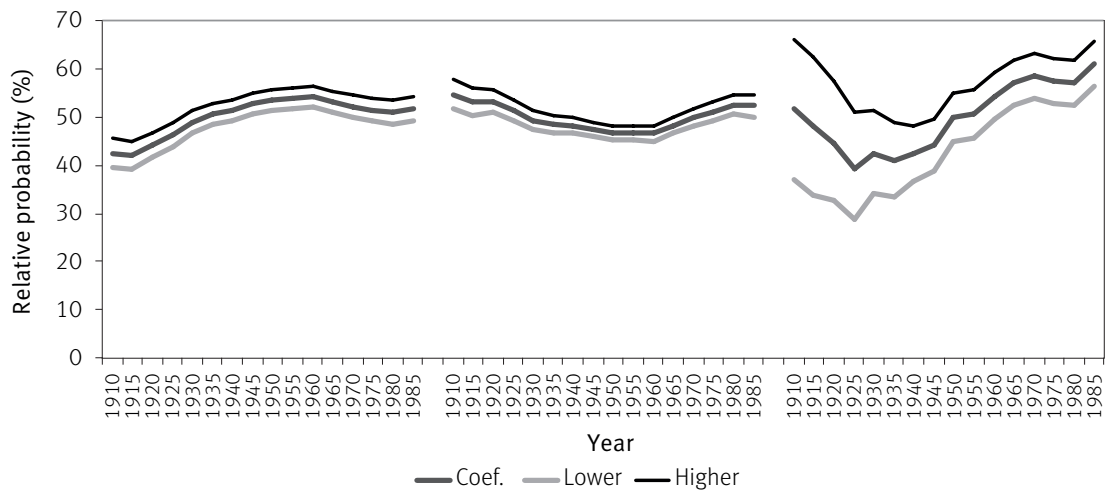

Source: IBGE. Brazilian Demographic Censuses of 1980, 1991, 2000, and 2010.

The descriptive analysis in Table 1 showed a sharp increase in the number of Pentecostals between 1980 and 2000. Sex ratios were low, degree of urbanicity were higher than the mean population, educational levels were lower, and age profiles were similar to the overall population.

The model in Table 4 confirmed some of these results, bringing positive coefficients to the urban dummy. The age coefficient was positive and the age-squared was negative, indicating a concave relationship. The maximum probability of being Pentecostal was seen to be around age 44, but differences between the age groups were not large. The regional dummies were mostly negative, indicating that Pentecostal churches were relatively more popular in the Central-Western Region. One exception is seen for the North, with a positive coefficient. This finding is in agreement with the theoretical section of this paper that explained how Pentecostal churches arrived in Brazil in this region.

Previously, we hypothesized that period effects could have caused a major increase in Pentecostalism and neo-Pentecostalism. These effects might be associated with historical vicissitudes that occurred in Brazil in recent decades, such as the economic crisis of the 1980 s and the increase in crime and violence in the 1990s. The coefficients for the random effects related to the period effects were negative or non-significant. As shown in Graph 1(B), however, period effects were clear for Pentecostals. We observed an increasing trend in the period, mostly between 1980 and 2000. After this year, the slope is less remarkable, possibly due to the growth of neo-Pentecostal churches.

We also stated that, due to cohort effects, younger cohorts would probably show a greater likelihood of being Pentecostal when compared with older cohorts. Alves, Barros and 
Cavenaghi (2012) found an increase in Pentecostals among children, who are now beginning to be born into this group, while some acquire it through conversion. Graph 2(B) shows the results for the cohort effects, which are based on the random effects coefficients of the intercepts and cohorts. Although the effects were smaller than those seen for period effects, the results indicate that cohorts born after 1970 had a greater likelihood of being affiliated with Pentecostal churches than cohorts born between 1940 and 1960. Older cohorts also had a greater probability of being Pentecostals, perhaps, as already acknowledged, because they may be more religious than younger cohorts.

We anticipated that the relative number of individuals with low educational levels in Pentecostal churches would be higher than that of persons with more education. Graph 3, based on the coefficients of education and the higher education variables, shows that the likelihood of being a Pentecostal decreases with years of formal education, especially for people with at least some college education and those with college degrees. Graph 4(A), plotting the coefficients of random effects of higher education and cohorts, shows that the decreasing effect of education on the propensity of being Pentecostal is less effective for younger cohorts. This is possibly because younger cohorts tend to be more homogenous in relation to their level of education, i.e., less socially selective regarding levels of education. The random effects of higher education and period were all non-significant, and we do not discuss these results further.

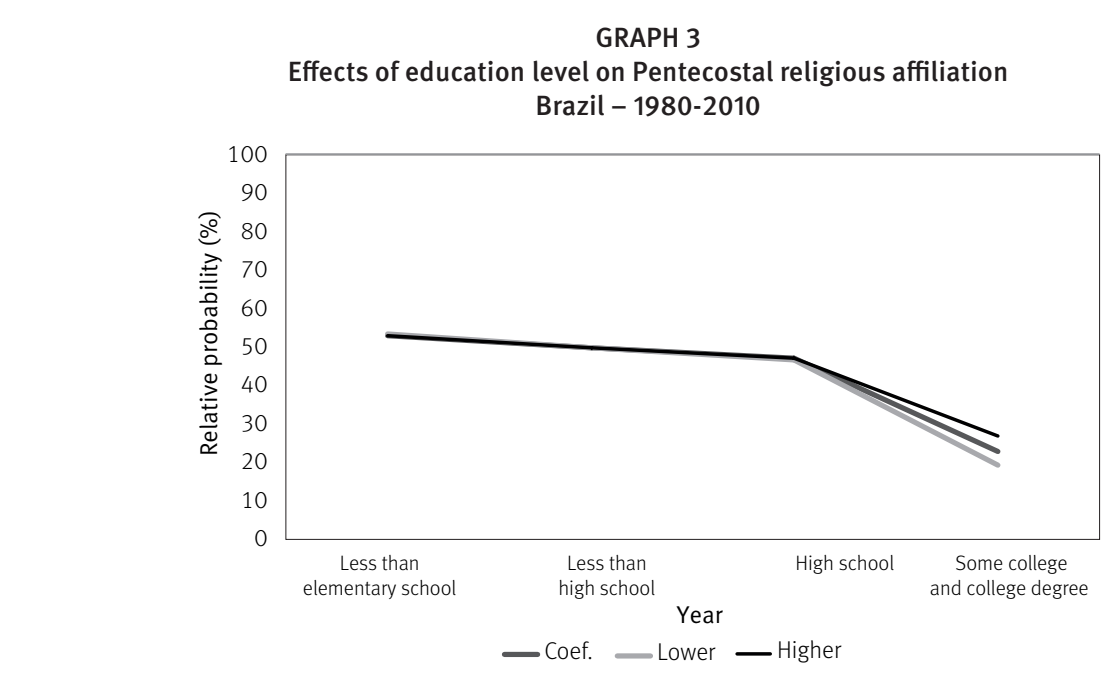

Source: IBGE. Brazilian Demographic Censuses of 1980, 1991, 2000, and 2010.

We expected Pentecostalism to be more popular among women. The coefficient of the fixed effect associated with sex was negative and significant, supporting this expectation. Many random effects for sex and cohorts were negative and significant. Graph 5(A) shows the results graphically. Notice that there are no differences between cohorts: women show greater likelihood of being Pentecostals in all cohorts. 
GRAPH 4

Effects of having higher education on birth cohorts on Pentecostal and no-religious-affiliation groups Brazil - 1980-2010

A B

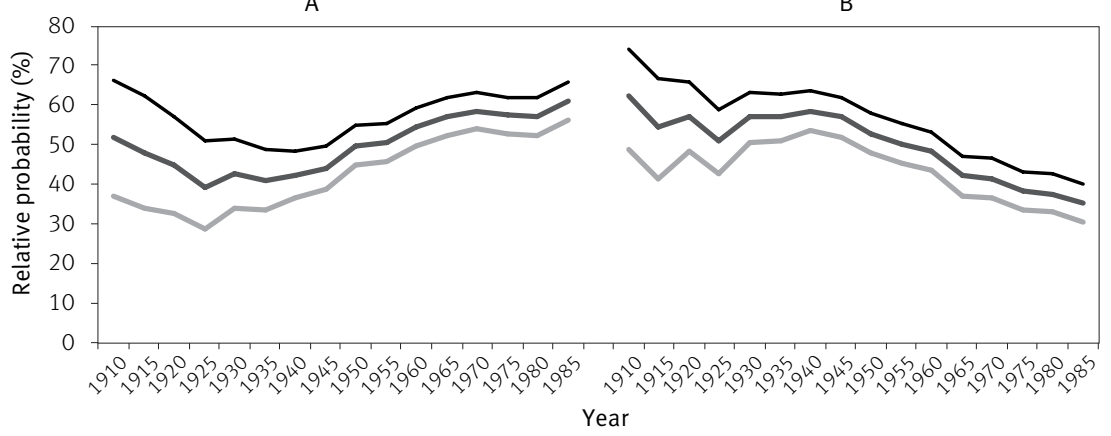

— Coef. — Lower — Higher

Source: IBGE. Brazilian Demographic Censuses of 1980, 1991, 2000, and 2010.

GRAPH 5

Sex effects for birth cohorts on Pentecostal and no-religious-affiliation groups

Brazil - 1980-2010

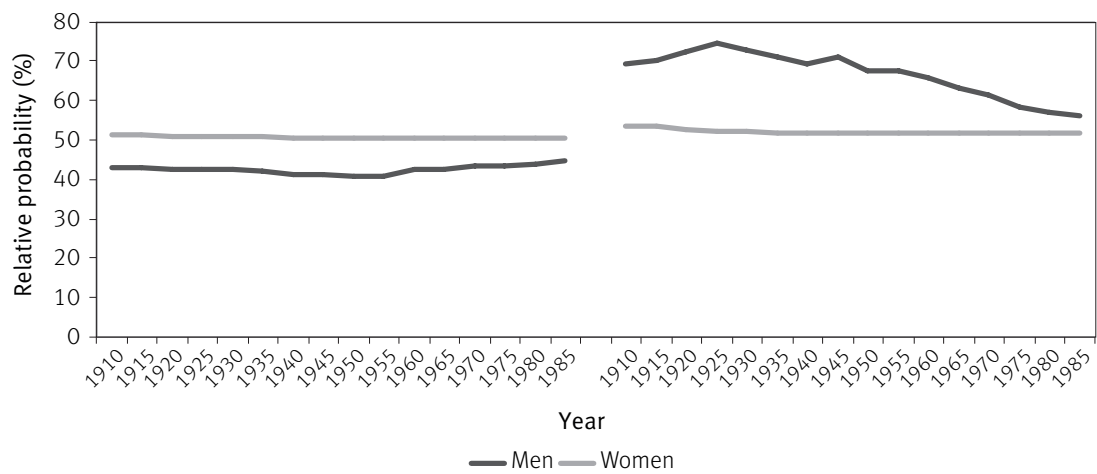

Source: IBGE. Brazilian Demographic Censuses of 1980, 1991, 2000, and 2010

Finally, we discuss the results for the group of people with no religious affiliation. We observed in the descriptive section of this paper that membership in this group has increased sharply in recent years. The category also showed very high sex ratios, higher level of urbanicity, and younger ages of its members. Differences in educational level, however, were not extraordinary.

The econometric model presented negative and significant signs for age and age-squared. This decreasing effect of age on the probability of being included in the group of people with no religious affiliation is shown in Graph 6. For Catholics, the relationship was convex with a minimum, and for Pentecostals it was concave with a maximum. These two age profiles were not exceptional. On the other hand, the age effect net of cohort and period effects for "no affiliation" is very clear. The older the person, the less likely he/she will be to report "no affiliation," endorsing the theoretical expectations. 
GRAPH 6

Age effects of not having a religious affiliation

Brazil - 1980-2010

Source: IBGE. Brazilian Demographic Censuses of 1980, 1991, 2000, and 2010

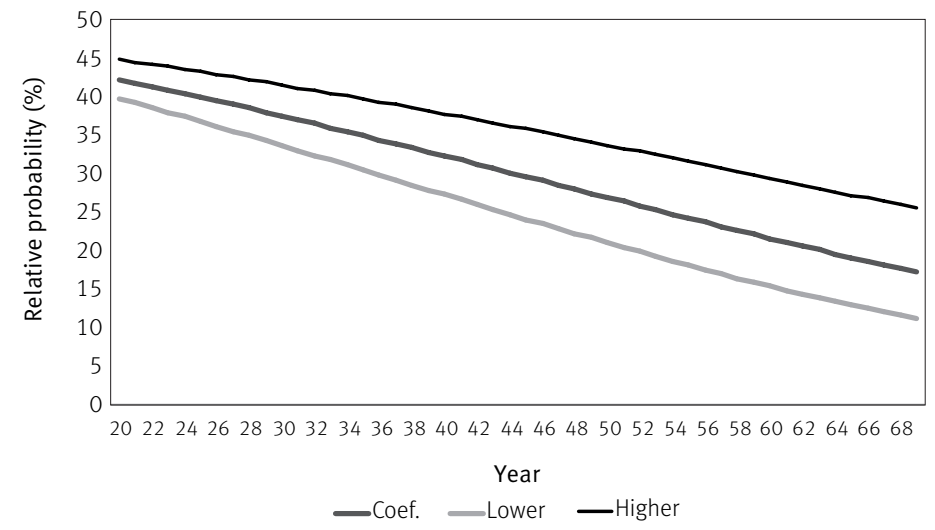

The coefficient for the urban dummy was positive, suggesting a more secular attitude of more urban individuals. The regional dummies were positive for the Southeast, which is the most industrialized region of the country, and negative for the other regions.

Graph 1(C) shows that net of cohort and age effects, period effects increased between 1980 and 2000, although they were not significant. However, the coefficients for 2010 declined and changed this trend considerably. Even though we observed an increase in the number of non-affiliated individuals, period effects counterbalance this effect because of the increase in general religious affiliation in Brazil. Is this trend linked to demographic and social changes? Graph 1(C) suggests that part of the explanation for the drop in period effects for no-affiliation might be due to population aging.

In the theoretical presentation above we stated that "No religious affiliation" would be reported more often by younger generations, representing a cohort effect. Most random effects associated with the coefficients for the intercept and cohort were not significant, but we did observe significant negative values for cohorts born between 1935 and 1954 and positive values for cohorts born after 1975. Graph 2(C) presents these results graphically. We observe that younger cohorts were in fact more prone to be in the "No Religious affiliation" group, but the effects were rather small.

In the econometric model, we also noted a positive coefficient for the male dummy, corroborating the findings of the descriptive analysis. In addition, Graph 5(B) presents the random effects of sex and cohort, men showing a greater likelihood of being in the no-religious affiliation group in all cohorts, but with the gender gap becoming narrower.

Finally, we discuss the effects of education on lack of affiliation. First, we note that while the fixed effects coefficient of education were negative and of small magnitude, the coefficient for high education was positive and large. These findings indicate that it is not the increasing level of schooling, but a post-secondary degree that increases the likelihood of having no affiliation. 
Graph 7 shows the period effects associated with higher education. The results for the period effect suggest that when higher education was more selective, i.e., most of the population had low levels of educational attainment, as in 1980, the higher the educational level, the higher the probability of being in the "No religious affiliation" group. This result is becoming weaker, however, possibly because overall levels of education have recently increased and are more homogeneous for younger cohorts.

\section{GRAPH 7}

Education and period effects for the no religious affiliation group Brazil - 1980-2010

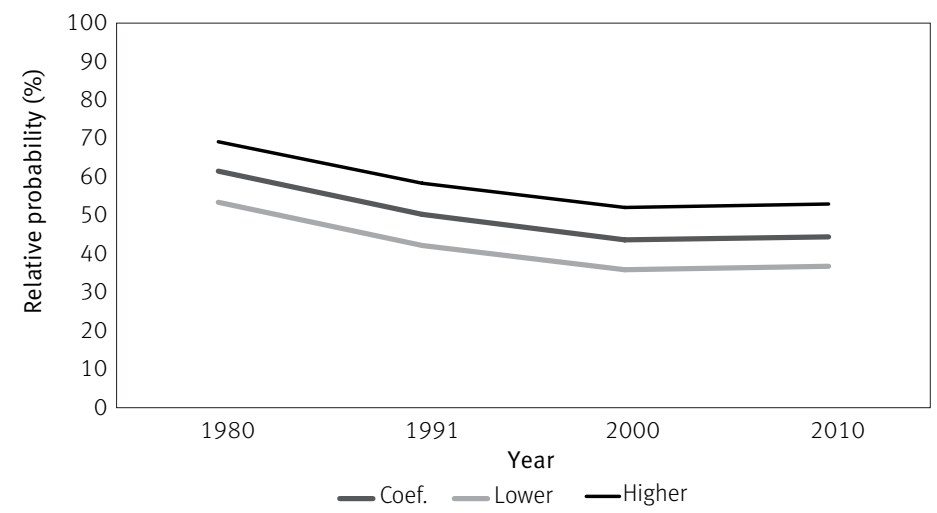

Source: IBGE. Brazilian Demographic Censuses of 1980, 1991, 2000, and 2010.

Graph 4(B) complements this discussion with coefficients for education and cohort. For individuals born before 1950, more education implies a higher probability of being in the "No religious affiliation" group. The contrary is observed for younger cohorts. These results suggest that education does have an impact on religious affiliation but the threshold is relative to the levels of education of the overall population.

\section{Conclusions}

The main objective of this paper was to analyze the age, period, and cohort effects associated with religious affiliation in Brazil between 1980 and 2010. We applied the Hierarchical Age-Period-Cohort (HAPC) and Cross-Classified Random Effects Model (CCREM), which overcomes many of the limitations that previously plagued the APC approach. Using this method, we were able to disentangle the effects of age, period and cohort and illuminate some of the factors that are responsible for the changing landscape of religious affiliations in Brazil.

Alves, Barros and Cavenaghi (2012) emphasized that if current trends do not change substantially, less than $50 \%$ of Brazil's population will be Catholic within 20 or 30 years. One of the indications of this trend is the fact that evangelicals have already surpassed Catholics among the young people. In some regions in Brazil that are considered leaders in the process of convergence towards plurality, such as the states of Rio de Janeiro, Rondônia and Roraima, 
Catholics were already a minority in 2010. We performed illustrative simulations based on the coefficients of the models (results not shown). In agreement with the results of the study mentioned above, we found that Catholics are likely to become a minority in Brazil between 2025 and 2035.

We also noted that age effects were significant but of small magnitude for both Catholics and Pentecostals. On the other hand, they were substantial for persons with no religious affiliation, with a negative relationship between age and probability of membership in this group. For both of these religious affiliations, period effects were of greater magnitude with clear trends, negative for Catholics and positive for Pentecostals. Cohort effects were significant for all three affiliations, but magnitudes were smaller than the other two effects.

Based on those findings, we found support for our hypothesis that important events or historical conjunctures that took place in past decades, such as the economic crisis, may have indeed contributed to period increases for Pentecostals. Future studies should investigate the mechanisms by which Pentecostal churches establish themselves in poor urban areas and how they attract and convert new members, especially older persons, since their mechanisms toward young Brazilians have already been clarified elsewhere (VERONA, 2010). Similarly, the period increases in non-affiliation could have been driven either by an increase in general levels of education or by the increasing level of urbanicity over recent decades.

We observed that the likelihood of being a Pentecostal decreased with formal education, especially for those with some college education and a college degree. This deterrence was less effective, however, for younger cohorts, possibly due to the increase in the growing enrollment in higher education enrollment and attainment that might have democratized access to post-secondary education and may have caused students with higher educational levels to be less selective. Although no causality can be determined given that longitudinal data is not available, higher educational levels seem to be associated with an increase in those with no religious affiliation. Nonetheless, similar to what was stated above, this result is becoming weaker for the younger cohorts, possibly because the overall levels of education have increased over time.

This finding has important implications for the future. In a country where religious values have heavily influenced policymaking, such as in the case of abortion laws and same sex marriage, should we expect the country to become more politically conservative if Pentecostals significantly increase their proportion in the population, or would the increase in education level be sufficient to lessen conservative attitudes?

More questions emerge from this debate, however. Is the country moving toward polarization? Can we expect other strong forces to emerge? Might the CCR ally with Pentecostals and nominal Catholics ally with persons with no affiliation? How will population aging affect religious affiliations? How is the current economic crisis shaping affiliations? Would the fact that Pope Francis (voted in 2013) is Argentinian and the World Youth Day 2013 was 
held in Rio de Janeiro cause a period effect to increase numbers of Catholics in the Census of 2020 ? Will the same relationships found in this paper hold over time? Only time will tell.

Timing is crucial. The HAPC/CCREM approach is used in Life Course Research because it can empirically demonstrate how people's life histories are embedded in social and cultural contexts, in fact, embedded in time. APC effects, in general, should be included in demographic analysis, but, they are usually ignored by research given the limitation of Brazilian databases. It is time to reconsider data collection and analysis to embrace longitudinal perspectives and to investigate how life shapes and is shaped by period, age and cohort, that is, where we are in history as we age. In the meantime, in the absence of longitudinal data, methods such as that used in this paper can shed light on people's life courses. We believe that other demographic topics of research such as health behavior, fertility decisions and causes of death could also benefit from using an APC perspective.

By demonstrating that affiliations are impacted by historical period, but also by age and cohort independently, we contribute to the literature on religion and religiosity by dialoguing with other researchers who inform us of the meaning of religious affiliation and how it influences and is impacted by the life course. In addition, our findings show the intersections of religion with gender, education and urbanicity, but there is still unexplored ground for research on other characteristics, such as race and marital status, which often shape one's life course, and the social and general transmission of religious attitudes and behavior, as explored by Almeida and Barbosa (2013).

We also saw that Pentecostalism was more popular among women than men in all cohorts. Men showed a greater likelihood to be in the group with no religious affiliation in all cohorts, but the differences are diminishing. Future research should investigate how the meaning of religious affiliation and other aspects of religiosity may vary by gender and might be changing over time. Are men more skeptical? Do women and men play the same roles, share the same views and have the same spiritual and economic gains when they attend religious services? Is there any social networking operating in the way churches attract female members? What could explain the narrowing gap? The relationship between the gender gap in religiosity and the recent increase in female autonomy and control in the household also deserves future studies.

In sum, religious affiliation has the potential to affect many social aspects in Brazil, as religion is likely to influence one's view toward the world by creating and sharing symbolic meanings and by shaping social and political attitudes. Better understanding of these trends seen from these perspectives will surely enhance the possibility of further unveiling different aspects of many social and demographic phenomena in Brazil.

At this point, researchers have been busy understanding trends, but little is known about the major consequences we can expect as the Brazilian religious transition unfolds. Future studies should deepen our knowledge about how religious groups differ in terms of their economic practices, political attitudes, and social behavior. 


\section{References}

ALMEIDA, R.; BARBOSA, R. Transição religiosa no Brasil. Centro de Estudos da Metrópole, 2013. Mimeografado.

ALMEIDA, R.; MONTERO, P. Transito religioso no Brasil. 2013. Available at: 〈http://www.fflch.usp.br/ centrodametropole/antigo/v1/pdf/ronaldo_almeida2.pdf〉.

ALVES, J. E. D.; BARROS, L. F. B.; CAVENAGHI, S. A dinâmica das filiações religiosas no Brasil entre 2000 e 2010: diversificação e processo de mudança de hegemonia. Rever - Revista de Estudos da Religião, v. 12, n. 2, p. 145-174, 2012.

ALVES, J. E. D.; NOVELLINO, M. A dinâmica das filiações religiosas no Rio de Janeiro: 1991-2000. Um recorte por educação, cor, geração e gênero. In: PATARRA, N.; AJARA, C.; SOUTO, J. (Eds.). 0 Rio de Janeiro continua sendo... Rio de Janeiro: Ence/IBGE, 2006, p. 275-307.

BELL, A.; JONES, K. Another 'futile quest'? A simulation study of Yang and Land's Hierarchical Age-PeriodCohort model. Demographic Research, v. 30, p. 333-360, 2014.

BURDICK, J. Struggling against the devil: Pentecostalism and social movements in urban Brazil. In: GARRARD-BURNETT, V.; STOLL, D. (Eds.). Rethinking Protestantism in Latin America. Philadelphia: Temple University Press, 1993, p. 20-44.

CHESNUT, A. Born again in Brazil. The Pentecostal boom and the pathogens of poverty. New Brunswick, NJ: Rutgers University Press, 1997.

Born again in Brazil: spiritual ecstasy and mutual aid. In: GARRARD-BURNETT, V. (Ed.). On Earth as it is in heaven: religion in modern Latin America. Wilmington, DE: Scholarly Resources, 2000, p. 219-234 (Jaguar Books on Latin America, 18).

COSTA, J.; MELLO, L.; OJIMA, R. Religion and fertility: understanding adolescence pregnancy and family religion. In: IUSSP CONFERENCE, Avaiable at: <http://iussp2005.princeton.edu/download. aspx?submissionld=51318>. Accessed on: 11. Jan. 2011.

COUTINHO, R. A carne é fraca: religião, religiosidade e iniciação sexual entre estudantes do Ensino Médio na Região Metropolitana de Belo Horizonte, 2008. Dissertação (Mestrado em Demografia) Centro de Desenvolvimento e Planejamento Regional. Universidade Federal de Minas Gerais, 2011.

DECOL, R. Mudança religiosa no Brasil. Uma visão demográfica. R. bras. Est. Pop., v. 16, n.1/2, p. 121-137, 1999.

FERNANDES, A.; PAES, C. A economia brasileira na década de 80: consequências da crise da dívida externa, inflação e crise do Estado. Available at: 〈http://www2.egi.ua.pt/xxiiaphes/Artigos/a\%20 Fernandes\%20onInflama\%C3\%A7\%C3\%A3o.PDF〉. Accessed on: 03 Mar. 2011.

FRAGOSO, H. Presença franciscana no Brasil em cinco séculos de evangelização. In: CEFEPAL. Entre memória e utopia. Primeiro capítulo nacional da família franciscana. Brasília: Cefepal, 1994, p. 32-65.

FRESTON, P. Brother votes for brother: the new politics of Protestantism in Brazil. In: GARRAD-BURNETT, V.; STOLL, D. (Eds.). Rethinking Protestantism in Latin America. Philadelphia: Temple University Press, 1993, p. 66-110.

FU, W. A smoothing cohort model in age-period-cohort analysis with applications to homicide arrest rates and lung cancer mortality rates. Sociological Methods and Research, v. 36, p. 327-61, 2008.

IBGE. Características gerais da população, religião e pessoas com deficiência. Rio de Janeiro: Instituto Brasileiro de Geografia e Estatistica - IBGE, 2010.

LEVIN, J.; CHATTERS, L.; TAYLOR, R. Theory in religion, aging, and health: an overview. J Relig. Health, V. 50, n. 2, p. 389-406, 2011. 
MARIANO, R. Expansão pentecostal no Brasil: o caso da Igreja Universal. Estudos Avançados, v. 18, n. 52, p. 121-138, 2004

MASON, W.; SMITH, H. Age-period-cohort analysis and the study of deaths from pulmonary tuberculosis. In: MASON, W.; FIENBERG, S. (Eds.). Cohort analysis in social research. New York: Springer-Verlag, 1985, p. 151-228.

MCKINNON, S.; POTTER, J.; GARRARD-BURNETT, V. Adolescent fertility and religion in Rio de Janeiro, Brazil in the year 2000: the role of Protestantism. Population Studies, v. 62, n. 3, p. 289-303, 2008

MINNESOTA POPULATION CENTER. Integrated Public Use Microdata Series, International: Version 6.1. Available at: 〈www.ipums.org〉. Accessed on: 06 Jun. 2011.

OLIVERIA, M. A. Entre a coroa e a cruz: a igreja colonial sob a égide do padroado. Mneme - Revista de Humanidades, v. 9, n. 24, 2008. Available at: 〈http://www.cerescaico.ufrn.br/mneme/anais/st_trab_pdf/ pdf_st3/marlon_oliveira_st3.pdf>. Accessed on: 11 Jan. 2011.

PIERUCCI, A. F. "Bye bye, Brasil" - O declínio das religiões tradicionais no Censo 2000. Estudos Avançados, v. 18, n. 52, 2004.

RYDER, N. The cohort as a concept in the study of social change. American Sociological Review, V. 30, n. 6, p. 843-861, 1965.

$\mathrm{SMITH}$, C. Theorizing religious effects among American adolescents. Journal for the Scientific Study of Religion, v. 42, n. 1, p. 17-30, 2003.

SOUZA, S. D. (Org.). Gênero e religião no Brasil: ensaios feministas. São Bernardo do Campo: Editora da Umesp, 2007.

STEENSLAND, B.; PARK, J.; REGNERUS, M.; ROBINSON, L.; WILCX, W.; WOODBERRY, R. The measure of American religion: toward improving the State of the Art. Social Forces, v. 79, n. 1, p. 291-318, 2000.

VAN DE KAA, D. J. Europe's second demographic transition. Population Bulletin, v. 42, n. 1, 1987.

VERONA, A. P. A. Sexual initiation and religion in Brazil. Dissertation (Ph.D. in Sociology) - University of Texas at Austin, 2010.

YANG, Y. Aging, cohorts, and methods. In: BINSTOCK, R.; GEORGE, L. (Ed.). The handbook of aging and the social sciences. London: Elsevier, 2011, p. 17-30.

YANG, Y.; FU, W.; LAND, K. A methodological comparison of age-period-cohort models: intrinsic estimator and conventional generalized linear models. Sociological Methodology, v. 34, p. 75-110, 2004.

YANG, Y.; LAND, K. Age-period-cohort analysis of repeated cross-section surveys: fixed or random effects? Sociological Methods and Research, v. 36 (special issue), p. 297-326, 2008.

. Age-period-cohort analysis: new models, methods, and empirical applications. Chapman \& Hall/CRC Interdisciplinary Statistics, 2013.

YANG, Y.; SCHULHOFER-WOHL, S.; FU, W.; LAND, K. The intrinsic estimator for age-period-cohort analysis: what is it and how to use it. American Journal of Sociology, v. 113, n. 6, p. 1697-1736, 2008.

\section{Authors}

Raquel Zanatta Coutinho is a teaching fellow/PhD graduate student at the University of North Carolina at Chapel Hill/Department of Sociology/Carolina Population Center. She has a master degree in Demography from Cedeplar-UFMG.

André Braz Golgher has a doctoral degree in Demography from Cedeplar-UFMG, and is currently a professor at Cedeplar-UFMG. 


\section{Correspondence address}

Raquel Zanatta Coutinho

University of North Carolina at Chapel Hill

155 Hamilton Hall, CB 3210

Chapel Hill, NC 27599, USA

\section{Resumo}

Um estudo sobre a filiação religiosa no Brasil entre 1980 e 2010: efeitos de idade, período e coorte Houve uma marcante redução no número relativo de católicos no Brasil nas últimas décadas, fato que é associado, principalmente, ao crescimento das igrejas pentecostais e neopentecostais, bem como ao aumento no número de pessoas sem filiação religiosa. Foram analisados os efeitos de idade, período e coorte associados à filiação religiosa no Brasil entre 1980 e 2010, com o uso do modelo idadeperíodo-coorte hierárquico e modelos de efeitos randômicos com classificação-cruzada. Observaramse efeitos de idade significativos, mas de pequena magnitude para católicos e pentecostais, e efeitos substanciais para aqueles sem filiação religiosa, sendo essa com uma relação negativa. Para as duas primeiras afiliações, os efeitos de período eram de maior magnitude e com tendências claras: negativa para católicos e positiva para pentecostais. Os efeitos de coorte foram significativos para as três afiliações, mas as magnitudes foram menores do que para dos dois outros efeitos. Também verificou-se que a propensão em ser pentecostal diminui com o nível de educação, sendo que o contrário ocorre para pessoas sem religião. Entretanto, esses efeitos são menos marcantes para coortes mais jovens, possivelmente por causa da natureza menos seletiva da educação superior atualmente no Brasil e do aumento generalizado dos níveis de educação.

Palavras-chave: Afiliação religiosa. Idade-período-coorte. Modelos de efeitos randômicos com classificação-cruzada. Brasil.

\section{Resumen}

El cambio de panorama de las afiliaciones religiosas en Brasil entre 1980 y 2010: perspectivas de edad, período y cohorte

Ha ocurrido una notable reducción en el número de católicos en Brasil en las últimas décadas, un hecho que se atribuye al crecimiento de las iglesias pentecostales y un aumento del número de personas sin afiliación religiosa. Analizamos los efectos de edad, período y cohortes asociadas a las afiliaciones religiosas en Brasil desde 1980 hasta 2010, aplicando modelos Jerárquico de Edad-Período-Cohorte y de Efecto Aleatorio de Clasificación Cruzada. Observamos que los efectos de edad fueron significativos pero de baja magnitud para católicos y pentecostales, mientras fueron sustanciales para aquellos sin afiliación religiosa, con una relación negativa. Para las dos primeras afiliaciones religiosas, los efectos de período fueron de mayor magnitud y presentaron tendencias claras: negativas para los católicos y positivas para los pentecostales. Los efectos de cohorte fueron significativos para todas las tres afiliaciones, pero las magnitudes fueron menores que los otros dos efectos. También verificamos que la propensión a ser pentecostal se reduce con la educación formal, y lo opuesto ocurrió con las personas sin afiliación religiosa. Sin embargo, tales efectos fueron menores para cohortes más jóvenes, posiblemente debido a la reducción de la selectividad social de estudiantes recientes en búsqueda de una educación más alta y al aumento general en todos los niveles de educación.

Palabras-claves: Afiliación religiosa. Análisis de Edad-período-cohorte. Modelos de efectos aleatorios de clasificación cruzada. Brasil. 